Apidologie, 1985, 16 (2), 181-184

RAPID COMMUNICATION

\title{
INFLUENCE OF AGE ON THE FLUCTUATION OF IRON IN THE OENOCYTES OF HONEY BEE (APIS MELLIFERA) DRONES
}

\author{
Gerald M. LOPER \\ U.S. Department of Agriculture, Agricultural Research Service, \\ Carl Hayden Bee Research Center, Tucson, AZ 85719
}

\section{SUMMARY}

\begin{abstract}
Since the discovery of magnetite in biological organisms including honey bees, localization in the organism and specific functions have been sought. Groups of cells (oenocytes) located in the abdomen of honey bee workers and queens have been found to contain iron-rich granules. Now, for the first time, these granules are reported in honey bee drones, but the concentration appears to be age-related. Oenocytes of drones only 0 - and 3-days old did not stain positively for iron, while those of 6-, 9- and 12-days did. A function relating the accumulation of iron with maturation, drone flight directionality, and the establishment of drone congregation areas is hypothesized.
\end{abstract}

\section{INTRODUCTION}

The apparent sole function of drones in a honey bee colony is to mate with virgin queens, an activity that first requires about 2 days of maturation (presumably physiological as well as sexual) after emergence (RuTTNER, 1966). Mating flights also require flight directionality since drones are known to collect in specific drone congregation areas (DCA's) independent of the presence of a queen generally 10 to 25 meters above ground and as far as 6-7 kilometers from the colony (Konapacka, 1969 ; RutTNer, 1966). It is not known how either the queens or drones locate these areas day-after-day (GERIG, 1972) although pheromones may play a supporting role (GARY, 1962 ; RUTTNER, 1966). It has been proposed that drones may orient by means of physical features of the landscape. Ruttner (1966) and van PraAgh (1975) reported a uniformity of the angular radiance distribution in DCA's that was unique relative to nearby areas outside the DCA. 
The presence of iron deposits with magnetic properties has been reported in honey bee queens and workers (Gould et al., 1978; Gould, 1980). To my knowledge, no reference to such inclusions occurring in honey bee drones exists in the literature, although Dr. Joe Kirschvink of California Institute of Technology, Pasadena, CA (pers. comm.) has found magnetic remanence in workers and drones. Up to the present, no one has presented any data ascribing any biological function to these deposits although Gould and KIRSCHvink hypothesized that magnetite in drones may assist them in finding DCA's (pers. comm.). In worker bees, a magnetic component in the recruiting «waggle $\gg$ dance has been demonstrated (Lindauer and Martin, 1968). Kuterbach et al. (1982) have suggested that the magnetic response in worker honey bees is localized in bands of cells (oenocytes) around each abdominal segment since they have shown that these cells contain iron as visualized using the Prussian blue stain. The purpose of this study was to determine whether drone oenocytes of all ages contained iron.

\section{MATERIALS AND METHODS}

One full-depth Langstroth frame with sealed drone comb was incubated at $33^{\circ} \mathrm{C}$. When at least 150 drones emerged in an $18 \mathrm{hr}$ period, these were transferred to a screen cage and placed in a normal colony where the drones could be fed and allowed to mature. On the first day (day « $0 »$ ), and on days $3,6,9$, and 12 , ten drones were removed, decapitated, the abdomens slit, and placed in $4 \%$ neutral, buffered formalin. After 2 days of fixing, the abdomens were opened and stained with Prussian blue (Kuterbach et al., 1982).

\section{RESULTS AND DISCUSSION}

Although the oenocytes were visible in all drones, stained granules were seen in older drones but not in the 0 - and 3-days old drones $(n=10$ for each day). These results indicate an age-related accumulation of iron related to maturity and/or possibly to biological functionality. It is necessary to perform additional age-related studies with more sophisticated techniques and to determine if these iron deposits play a role, either in drone flight orientation or some other biologically significant function. It should be noted that the mineral content of worker honey bees increases with age up to day 6 , and then stabilizes at a slightly lower level (DiETZ, 1971). Additionally, the levels of $\mathrm{P}, \mathrm{K}, \mathrm{Ca}, \mathrm{Mg}$, and $\mathrm{Na}$ generally increased to $150-200 \%$ above the day $\ll 0 »$ levels and iron increased about $460 \%$ above the day $\ll 0 \gg$ levels. Young drones ( 0 - to 3-days old), besides being sexually immature, may be incapable of directional flight until sufficient iron has 
been accumulated in the oenocyte cells and converted biologically to magnetite. Recently, KIRSCHVINK and co-workers presented a paper at the meeting of the American Geophysical Union [reported by WeISburd (1984)] in Science News describing a correlation between the orientation of whales and magnetic anomalies suggesting that whales use magnetic highs « as a kind of anchor point ».

I hypothesize that honey bee drones may be using a combination of cues including magnetic sensitivity to locate drone congregation areas.

Received for publication in February 1985.

Accepted for publication in March 1985.

\title{
ACKNOWLEDGEMENTS
}

The technical assistance of John EDWards who prepared, stained, and examined the samples is gratefully acknowledged.

\author{
RÉSUMÉ \\ INFLUENCE DE L'AGE SUR LA TENEUR EN FER DES GENOCYTES \\ DES MALES D'ABEILLE (APIS MELLIFICA L.)
}

\begin{abstract}
Depuis la découverte de la magnétite dans les organismes vivants, dont l'abeille, on a recherché sa localisation dans l'organisme et ses fonctions spécifiques. On a montré que des groupes de cellules (les cnocytes) situées dans l'abdomen des ouvrières et des reines d'abeilles contenaient des granules riches en fer. On signale aujourd'hui, pour la première fois, la présence de ces granules chez les mâles, mais leur concentration semble liée à l'âge. Les œnocytes des mâles âgés de 0 à 3 jours ne montrent aucune coloration liée au fer, contrairement à ceux des mâles âgés de 6,9 et 12 jours. On propose une hypothèse, selon laquelle la concentration en fer au cours de la maturation est liée au maintien de la direction de vol et à la formation de lieux de rassemblement de mâles.
\end{abstract}

\section{ZUSAMMENFASSUNG}

\section{DER EINFLUSS DES ALTERS AUF DEN EISENGEHALT DER OENOZYTEN VON HONIGBIENEN}

Seit der Entdeckung von Magnetit in Organismen, einschließlich der Honigbienen, hat man nach seiner Lokalisierung im Organismus und nach seiner Funktion gesucht. Es wurde festgestellt, daß Zellgruppen (Oenozyten) im Abdomen von Arbeitsbienen und Königinnen eisenreiche Granula enthalten. Jetzt wird zum ersten Mal über solche Granula bei Drohnen berichtet, aber ihre Konzentration ist offensichtlich altersabhängig. Die Oenozyten von 0 - bis 3-tägigen Drohnen zeigten keine positive Eisenfärbung, Drohnen von 6,9 und 12 Tagen Alter hingegen schon. Es wird die Hypothese aufgestellt, daß die Anreicherung mit Eisen während des Reifungsprozesses mit der Einhaltung der Richtung während des Drohnenfluges und mit der Entstehung von Drohnensammelplätzen in Zusammenhang stehen könnte. 


\section{REFERENCES}

Dietz A., 1971. - Changes with age in some mineral constituents of worker honey bees. I. Phosphorus, potassium, calcium, magnesium, sodium and iron. J. Ga. Ent. Soc., 6, 54-57.

GarY N., 1962. - Chemical mating attractants in the queen honey bee. Science, 136, 773-774.

Gerig L., 1972. - Ein weiterer Duftstoff zur Anlockung der Drohnen von Apis mellifica (L.). Z. angew. Entomol., 70, 286-289.

Gould J., KirschvinK J., Deffeyes K.S., 1978. - Bees have magnetic remanence. Science, 201, 1026-1028.

Gould J., 1980. - The case for magnetic sensitivity in birds and bees (such as it is). Amer. Sci., 68, 256-267.

KonaPACKA Z., 1969. - Studies on distance of mating flights of honey bee queens and drones and the necessary isolation of mating stations for preventing mismatings. Dept. Bee Culture, Research Institute of Pomology, Poland. Final Report. 22 p.

Kuterbach D.A., Walcott B., Reeder R.J., Frankel R.B., 1982. - Iron-containing cells in the honey bee (Apis mellifera). Science, 218, 695-697.

Lindauer M., Martin H., 1968. - Die Schwereorientierung der Bienen unter dem Einfluss der Erdmagnetfelds. Z. Vergl. Physiol., 60, 219-243.

RUtTNER F., 1966. - The life and flight activity of drones. Bee World., 47, 93-100.

VAN PraAgh J.P., 1975. - Drone orientation; optical environment at drone congregation areas. Proc. 25th Int. Apimondia Congr., Grenoble, 274-276.

Weisburd S., 1984. - Whales and dolphins use magnetic «roads ». Science News, $25 \& 26,391$. 